\title{
Description of Science Process Skills of Physics Education Students of Jambi University on Refraction Material on Concave Lenses Using E- Module
}

\author{
Irawati $^{1}$, Aziza Putri Ningsi ${ }^{2}$ \\ ${ }^{1}$ Junior High School Durian Remuk, Sumatera Selatan, Indonesia \\ ${ }^{2}$ Physics Education, Universitas Jambi, Jambi, Indonesia
}

\section{Article Info}

Article history:

Received Jan 3, 2021

Revised Jan 16, 2021

Accepted Jan 25, 2021

\section{Keywords:}

E - Module

Physics

Science Process Skills

\begin{abstract}
ABSTRAK
Purpose of the study: This study was conducted to determine the science process skills of physics education students for refraction material on a concave lens. The questions discussed in this study are to describe the basic and integrated science process skills of Jambi University physics education students, what are the obstacles faced when the implementation of the emodule basic physics practicum II is applied, what are the solutions to the obstacles faced.
\end{abstract}

Methodology: This study uses a quantitative approach with descriptive methods. This research was conducted in the Physics Education Laboratory of the Teacher Training and Education Faculty, Jambi University. The sample 1 in this study were 40 physics education students contracting basic physics II subjects. The sampling technique used in this study was a total sampling technique.

Main Findings: With the use of a Manual for Basic Physics 1 practicum in the form of e-module, it can improve students' science process skills. It can be seen from the research results, that the science process skills of physics education students at Jambi University on refraction practicum material on concave lenses

Novelty/Originality of this study: With this research, students are motivated to improve science process skills so that they become more active and more familiar with the concept of learning and can improve learning outcomes. Through this research, students can become more innovative and creative teachers, and can also find out the extent of students' science process skills.

This is an open access article under the $\underline{C C B Y-N C}$ license

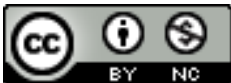

Corresponding Author:

Aziza Putri Ningsih,

Physics Education, Universitas Jambi, Jambi, Indonesia

Jl. Jambi-Ma. Bulia KM 15, Muaro Jambi, 36361, Jambi, Indonesia.

Email: azizap267@gmail.com

\section{INTRODUCTION}

Education is a conscious and planned effort to create an atmosphere of learning and the learning process for students to actively develop their potential [1-4]. Educators are expected to be able to impart characteristics, traits and dispositions as well as an independent spirit, responsibility and competence in life to students $[5,6]$. To improve the quality of education, various breakthroughs are needed, both in curriculum 
development, learning innovation, and the fulfillment of educational facilities and infrastructure [7,8]. Educators are expected to be able to impart characteristics, traits and dispositions as well as an independent spirit, responsibility and competence in life to students [9, 10]. There are several levels of education in Indonesia, ranging from basic education, secondary education and higher education.

The Jambi University Physics Education Study Program is one of the higher educational institutions that have graduate standards to be achieved consisting of: attitudes, knowledge, and skills. Physics is a branch of science that has its own uniqueness and characteristics [11]. Physics is a subject that deals with various scientific concepts, some of which can be found in everyday life [12,13]. Physics also discusses how to find out about nature systematically, so that science learning is a process of experiencing and resulting in the acquisition of knowledge in the form of understanding concepts [14, 15]. According to graduate competency standards, learning objectives include the development of the domains of attitudes, knowledge, and skills that are elaborated for each educational unit [16]. In accordance with technological advances and the development of science in the digital age, 21st century skills can be developed through scientific literacy skills and science processes, especially for science students [17].

There are several problems that often lead to the low achievement of physics learning objectives in lectures $[18,19]$. One of the causes of the success of the learning process is influenced by the quality and way of teaching a teacher. A teacher must have competence, because competence is a skill that must be possessed by a teacher as a provision in teaching [20]. The characteristics of a teacher are said to be professional if they already have four compulsory competencies, namely pedagogical competence, professional competence, social competence, and emotional competence [21].

According to [22], as a prospective teacher is required to have good pedagogical competence, where learning pedagogic competencies contain learning principles. A qualified teacher not only has knowledge, but also has skills. One of the skills a teacher must have is science process skills. Science process skills must be possessed by prospective physics teachers, so that when they become teachers, they can apply them to science process skills in the learning process in the classroom [23]. When a physics teacher or prospective physics teacher teaches using conventional methods, namely explaining the theory, it means that they do not have process skills $[24,11]$. When the process of teaching physics is carried out conventionally, students tend to only master physics concepts without knowing the process of these concepts [25, 26]. Students have difficulty understanding physics learning because physics is an abstract subject that requires high-level thinking to be able to understand it [27].

Thinking skills that help students learn through knowledge in order to solve problems and find solutions are science process skills [28]. Science process skills are the ability to process actions as well as scientific thinking in order to develop an understanding of scientific concepts to support subsequent abilities. Because science process skills are student learning outcomes that emphasize the learning process, activities, creativity, values and the application of student attitudes in everyday life [29]. Process skills consist of basic skills, where these basic skills will be the basis for further skill development [30]. Science process skills are divided into basic process skills and integrated process skills. In basic science process skills, there are six ability indicators consisting of observation, inference, measuring, communication, classification and prediction, while in integrated process skills consist of controlling variables, making operational definitions, formulating hypotheses, interpreting data, conducting experiments and finally designing experiment [31]. In this research, basic science process skills use predictive and conclusion indicators, and integrated science processes use indicators to define variables operationally and design experiments.

Science process skills can be developed through practicum activities in the laboratory using the concept of thinking skills that can improve science process skills. If laboratory practices use scientific-based guidelines, students will be more active and independent, so that they can improve their scientific attitudes through practical experiments [32, 12]. Practicum is one of the supporters of the quality of education that improves student process skills, namely science process skills [23, 33]. It turns out that in the field, there are still students and teachers who have not mastered science process skills so it is necessary to develop science process skills in education [34]. Therefore, it is necessary to conduct research with the aim of describing student process skills through basic physics practicum 2 on convex lens material using the e - module.

In modern times the development of technology is very advanced. This requires education to be continuously developed in accordance with the times [35]. The development of technology is very helpful for the youth of human work, one of which is in the field of education, which can make the practicum process easier by the existence of e-modules. The E - module has met the indicators as a modern and sophisticated learning medium that can be accessed via a smartphone and is also able to facilitate the development of students' science process skills [29]. With the use of the E-module, the practical module will be more durable, feel more concise and can also be accessed at any time via the smartphone so that it can save paper usage. The results of research [36] the use of smartphones in learning is very helpful in use and easy to carry anywhere because smartphones are more practical. According to [37], the use of hard copy-based practicum 
guides are so less effective and efficient that to facilitate this, media can be used to support the learning process, besides that, there is waste in the use of paper and it is difficult to carry it anywhere. The University of Jambi physics education study program aims to produce graduates who are skilled in various aspects of competence, especially skills competencies. This research was conducted with the aim of knowing the science process skills of physics education students for refraction material on concave lenses. The questions discussed in this study are to describe the basic and integrated science process skills of Jambi University physics education students, what are the obstacles faced when the implementation of the e-module basic physics practicum II is applied, what are the solutions to the obstacles faced.

\section{RESEARCH METHOD}

This research uses a quantitative approach with descriptive methods. This research was conducted in the Physics Education Laboratory of the Teacher Training and Education Faculty, Jambi University. The sample taken in this study was 40 physics education students who contracted two basic physics subjects. The sampling technique used in this study was a total sampling technique. Total sampling technique is a sampling technique if all members of the population are used as samples [38]. The sample of 40 students was formed into groups with each group consisting of four to five students, this is in accordance with the research objective, namely to describe the science process skills of physics education students of Jambi University. Each student uses a guide in the form of an e-module based on science process skills with refraction material on a concave lens. Furthermore, students in each group carried out practicum using the tools and materials provided by the researcher.

The instrument used in this study was the science process skills, observation sheet that was validated by an expert validator. What is observed in this research is the basic and integrated science process skills that students have when doing practical activities in the Physics Laboratory of Jambi University. This observation was assisted by observers totaling 25 people. The percentage for each indicator sought is then stated in several categories, namely the category Very Bad Not Good, Good, Very Good. Science process skills focused on this research are divided into two categories, namely basic science process skills and integrated science process skills. Two indicators of basic process skills were observed, namely predication and conclusion, on integrated process skills, there were also two indicators, namely defining variables operationally and designing experiments.

\section{RESULTS AND DISCUSSION}

The results of the data analysis of the mastery of science process skills in Physics Education students of Jambi University. 
Table 1.Description of basic and integrated science process skills indicators for physics education students at Jambi University, refraction material on concave lenses

\begin{tabular}{|c|c|c|c|c|c|c|c|}
\hline \multicolumn{8}{|c|}{ BASIC SCIENCE PROCESS SKILLS } \\
\hline \multicolumn{3}{|c|}{ Classification } & \multirow{2}{*}{$\%$} & \multirow{2}{*}{ Mean } & \multirow{2}{*}{ Median } & \multirow{2}{*}{ Min } & \multirow{2}{*}{$\operatorname{Max}$} \\
\hline Indicator & Interval & Category & & & & & \\
\hline Conclusion & $\begin{array}{l}1.00-1,75 \\
1,76-2,50 \\
2,51-3,25 \\
3,26-4.00\end{array}$ & $\begin{array}{l}\text { Very Bad } \\
\text { Not Good } \\
\text { Good } \\
\text { Very Good }\end{array}$ & $\begin{array}{l}7.5 \\
20 \\
50 \\
22.5 \\
\end{array}$ & 2.87 & 3.0 & 1.0 & 4.0 \\
\hline Total & & & 100 & & & & \\
\hline Prediction & $\begin{array}{l}1.00-1,75 \\
1,76-2,50 \\
2,51-3,25 \\
3,26-4.00\end{array}$ & $\begin{array}{l}\text { Very Bad } \\
\text { Not Good } \\
\text { Good } \\
\text { Very Good }\end{array}$ & $\begin{array}{l}5 \\
17.5 \\
35 \\
42.5 \\
\end{array}$ & 3.15 & 3.0 & 1.0 & 4.0 \\
\hline Total & & & 100 & & & & \\
\hline \multicolumn{8}{|c|}{ INTEGRATED SCIENCE PROCESS SKILLS } \\
\hline \multicolumn{3}{|c|}{ Classificaton } & $\%$ & Mean & Median & Min & Max \\
\hline Indicator & Interval & Category & $\%$ & Mean & svecuan & IVIII & IVIax \\
\hline Defining Variables Operationally & $\begin{array}{l}2.00-3.50 \\
3.51-5.00 \\
5.01-6.50 \\
6.51-8.00 \\
\end{array}$ & $\begin{array}{l}\text { Very Bad } \\
\text { Not Good } \\
\text { Good } \\
\text { Very Good }\end{array}$ & $\begin{array}{l}12.5 \\
17.5 \\
25 \\
45 \\
\end{array}$ & 6.26 & 6.0 & 2.0 & 8.0 \\
\hline Total & & & 100 & & & & \\
\hline Designing experiments & $\begin{array}{l}5.00-8.75 \\
8.76-12.50 \\
12.51-16.25 \\
16.26-20.00 \\
\end{array}$ & $\begin{array}{l}\text { Very Bad } \\
\text { Not Good } \\
\text { Good } \\
\text { Very Good }\end{array}$ & $\begin{array}{l}10 \\
20 \\
27.5 \\
42.5 \\
\end{array}$ & 15.1 & 15.0 & 5.0 & 20.0 \\
\hline Total & & & 100 & & & & \\
\hline
\end{tabular}

In this study, respondents used the e-module for Basic Physics Practices 2 material on refraction on concave lenses. The sample used in this study was 40 students. Process skills that are focused on in this study are basic process skills which include predictions and conclusions. The results of observations of basic science process skills in physics education students of Jambi University on refraction material on a concave lens are shown in Table 1.

Table 1 shows the percentage of observations for basic science process skills from 40 students found that conclusion skills had a percentage of $50.0 \%$ in the good category. For predictive skills it has a percentage of $42.5 \%$ and is included in the very good category. Table 1 shows the percentage of observations for the integrated science process skills of 40 students who found that the Oprational Defining Variable Skills had a percentage of $45 \%$ in the very good category. For experimental design skills, it has a percentage of $42.5 \%$ and is included in the very good category.

Science process skills are skills that a physics student as a prospective teacher must possess. Process skills are skills that are acquired through basic skills. Where these basic skills will develop higher skills. If a person cannot use science process skills then they will find it difficult to develop higher order thinking skills [39]. Process skills can also be used as a scientific method to train students' steps in finding something through experimental activities. Description of the results of science process skills on refraction material on the concave lens of physics education students at Jambi University in Table 1 observed process skills indicators (predictions, conclusions, Defining Variables Oprationally, designing experiments). Science process skills are very important for physics education students where they are trained to become teachers who will teach students and they will be directly involved in the experiment. Meaningful learning is learning that will be easy to remember and learning that can involve students directly. a teacher who is able to perform process skills will be good at helping students master process skills [40]. From the research results, it can be seen that the results of students' skill process skills can be said to be good, because most students are already skilled in doing practicum on refraction material on concave lenses, because refraction material has been 
studied at the junior high school level so that students already understand and do not. Foreigners anymore, so they are quite skilled.

In activities for basic KPS, the predicted results of KPS which have the largest percentage, namely $50 \%$, are a good category and show that the student is skilled and has skills. This can be seen from students being able to conclude the process in practicum activities. In addition to basic science process skills. The Emodule of basic physics practicum 1 also focuses on integrated science process skills. Where in the practicum activity, the refraction of the concave lens on the indicators defines the variables prationally, a percentage of $45.0 \%$ is obtained and the experimental design indicator results in a percentage of $42.5 \%$, the results obtained are high in terms of defining variables rational and designing experiments, this can happen based on the ability to conclude students who are skilled during practicum. Where the ability to conclude is a comprehensive skill that supports the mastery of further skills, including mastery of integrated science processes, namely the skills to define variables prationally and design experiments. Basic process skills are skills that support subsequent skill development, namely integrated process skills [41].

By using the e-module, it can improve students' science process visibility, seen from the indicators of basic and integrated science skills which have a high percentage. This is shown in Table 1 and Table 2. It can be seen that the e-module really helps and facilitates the student practicum process. Mobile based guide. The $\mathrm{E}$ - module is considered capable of solving problems of students who find it difficult to use the printed physics practicum module [37].

\section{CONCLUSION}

With the use of the Guidebook for Basic Physics 1 practicum in the form of e-module, it can improve students' science process skills, it can be seen from the results of the research, that the science process skills of students of physics education at Jambi University on refraction practicum material on concave lenses can be said to be quite skilled or good in accordance with the percentage results obtained. The use of e-modules also make students easier during practicum and does not cause obstacles that can make it difficult for students. It is expected that the physics education study program must always apply the processbased e-module manual to improve science process skills through practicum activities.

\section{ACKNOWLADGEMENT}

Researchers would like to thank Jambi University Physics education students and all those who support so that this research can be carried out.

\section{REFERENCES}

[1] Tanti, U. Rahmi, and H. Samparadja, "Pengaruh Model Problem Based Learning Terhadap Kemampuan Pemecahan Masalah Matematis Siswa Kelas Vii Smp Negeri 14 Kendari," J. Chem. Inf. Model., vol. 8, no. 2, pp. 1689-1699, 2020, doi: 10.1017/CBO9781107415324.004.

[2] Haryanto, Harizon, and N. K. Rantih, "Pengembangan Instrumen Penilaian Keterampilan Proses Dan Sikap Ilmiah Pada Materi Termokimia Kelas Xi Mia Sma Negeri 10 Kota Jamb,” J. Indo. Soc. Integ. Chem., vol. 8, no. 1, p. 21=53, 2015.

[3] M. D. W. Ernawati, Haryanto, and S. C. Nababan, “Analisis Penerapan Model Pembelajaran Kooperatif Numbered Head Together (Nht) Dan Pengaruhnya Terhadap Hasil Belajar Siswa Pada Materi Struktur Atom Di Kelas X Smkn 3 Kota Jambi,” J. Ind. Soc. Integ. Chem, vol. 9, no. 1, pp. 45-53, 2017.

[4] C. J. M. Maguil and Ismawan Prasetia Devi, "A New trend in understanding students' interest in learning science: microetnography,” Integr. Sci. Educ. J., vol. 1, no. 2, pp. 62-66, 2020, doi: 10.37251/isej.v1i2.72.

[5] N. Kurniawan and N. Nurlaili, "Kedisiplinan siswa terhadap objek mata pelajaran IPA di SMP Kabupaten Muaro Jambi,” Integr. Sci. Educ. J., vol. 1, no. 2, pp. 56-61, 2020, doi: 10.37251/isej.v1i2.73.

[6] G. Nugroho, "Analisis motivasi belajar siswa pada pembelajaran IPA di SDN 16/ii Sepunggur," Integr. Sci. Educ. J., vol. 1, no. 2, pp. 67-71, 2020, doi: 10.37251/isej.v1i2.67.

[7] B. Asfadi, U. Yelianti, and R. S. Budiarti, "Pengaruh Model Pembelajaran Berbasis Masalah (Problem Based Learning) terhadap Hasil Belajar Biologi Siswa Kelas X SMA N 3 Kota Jambi,” Biodik, pp. 1-8, 2014.

[8] R. Dewi, R. S. Budiarti, and M. Aina, "The Development Of Learner Activity Sheet- Carged Character Education With A Learning Model Of Guided Inquiry On Material Of Bacteria For Students Of Class X High School," Biodik, vol. 3, no. 1, pp. 17-26, 2017.

[9] Paino and W. Desmawan, "Analisis sikap siswa pada pembelajaran IPA di SDN 124/VIII Sidorejo Kabupaten Tebo," Integr. Sci. Educ. J., vol. 1, no. 2, pp. 51-55, 2020, doi: 10.37251/isej.v1i2.75. 
[10] S. Wati, "Peran Guru Kelas Dalam Meningkatkan Pemahaman Siswa Pada Pembelajaran IPA Melalui Pembelajaran Berbasis Etnosains," Integr. Sci. Educ. J., vol. 1, no. 2, pp. 46-50, 2020, doi: 10.37251/isej.v1i2.78.

[11] Tanti, H. Isnadi, and Maison, "Konstruksi dan Validasi Bahan Ajar Fisika Berbasis Problem-Based Learning (PBL) untuk Meningkatkan Keterampilan Generik Siswa,” J. Teach. Learn. Phys., vol. 5, no. 1, pp. 28-34, 2020, doi: 10.15575/jotalp.v5i1.6635.

[12] Maison, Astalini, D. A. Kurniawan, and S. Lintang Rofiatus, "Deskripsi Sikap Siswa Sma Negeri Pada Mata Pelajaran Fisika Student's,” EduSains, vol. 10, no. 1, pp. 160-167, 2018.

[13] Tanti, Maison, A. Mukminin, Syahria, A. Habibi, and Syamsurizal, "Exploring the relationship between preservice science teachers' beliefs and self-regulated strategies of studying physics: A structural equation model," J. Turkish Sci. Educ., vol. 15, no. 4, pp. 79-92, 2018, doi: 10.12973/tused.10247a.

[14] Tanti, D. A. Kurniawan, R. Perdana, and O. H. Wiza, "Comparison of Student Attitudes Toward Natural Sciences in Rural Middle Schools in Jambi Province,” Ta'dib, vol. 23, no. 1, p. 63, 2020, doi: 10.31958/jt.v23i1.1607.

[15] E. Sulistiani, R. S. Budiarti, and Muswita, "Analisis Kemampuan Berpikir Kritis Siswa Lintas Minat Pada Pembelajaran Biologi Kelas X SMAN 11 Jambi,” Biodik, vol. 2, no. 1, pp. 13-19, 2016.

[16] K. Hardiyanti, Astalini, and D. A. Kurniawan, "Sikap Siswa Terhadap Mata Pelajaran Fisika Di Sma Negeri 5 Muaro Jambi," J. Edufisika, vol. 3, no. 2, pp. 1-12, 2018.

[17] P. Turiman, J. Omar, A. M. Daud, and K. Osman, "Fostering the 21st Century Skills through Scientific Literacy and Science Process Skills," Procedia - Soc. Behav. Sci., vol. 59, pp. 110-116, 2012, doi: 10.1016/j.sbspro.2012.09.253.

[18] F. R. Basuki, Jufrida, W. Kurniawan, I. P. Devi, and O. Fitaloka, "Tes Keterampilan Proses Sains: Multiple Choice Format," J. Pendidik. Sains, vol. 7, no. 2, pp. 101-111, 2019.

[19] Abdurrahman, Gardjito, and S. R. Budiarti, "Pengembangan Lembar Kegiatan Siswa Berbasis Penemuan Terbimbing Pada Materi Struktur Dan Fungsi Jaringan Tumbuhan Kelas Xi Sma.,” vol. I, no. September, pp. 1-8, 2015.

[20] Asrial, Syahrial, D. A. Kurniawan, R. Perdana, and P. Nugroho, "Supporting Technology 4.0: Ethoconstructivist multimedia for elementary schools," Int. J. online Biomed. Eng., vol. 15, no. 14, pp. 54-66, 2019, doi: 10.3991/ijoe.v15i14.11365.

[21] S. Syahrial et al., "Increased Behavior of Students' Attitudes to Cultural Values Using the Inquiry Learning Model Assisted by Ethnoconstructivism," J. Educ. Sci. Technol., vol. 5, no. 2, p. 166, 2019, doi: 10.26858/est.v5i2.9670.

[22] A. Asrial, S. Syahrial, D. A. Kurniawan, and R. Septiasari, " Relationship of Pedagogical Competence and Science Competency of Elementary School Teacher Education,” vol. 8, no. 2, pp. 149-157, 2019, doi: $0.21070 /$ pedagogia.v8i2.1872.

[23] Darmaji, D. A. Kurniawan, A. Suryani, and A. Lestari, "An Identification Of Physics Pre-Service Teachers " Science Process Skills Through Science Process Skills -Based Practicum Guidebook," J. Ilm. Pendidik. Fis. AlBiRuNi, vol. 07, no. October, pp. 239-245, 2018, doi: 10.24042/jipfalbiruni.v7i2.2690.

[24] D. Darmaji, D. A. Kurniawan, and I. Irdianti, "Physics education students' science process skills," Int. J. Eval. Res. Educ., vol. 8, no. 2, pp. 293-298, 2019, doi: 10.11591/ijere.v8i2.28646.

[25] T. Tanti, J. Jamaluddin, and B. Syefrinando, "Pengaruh Pembelajaran Berbasis Masalah terhadap Beliefs Siswa tentang Fisika dan Pembelajaran Fisika," J. Ilm. Pendidik. Fis. Al-Biruni, vol. 6, no. 1, p. 23, 2017, doi: 10.24042/jpifalbiruni.v6i1.603.

[26] M. Naswir, Haryanto, and Ferawati, “Analisis Keterlaksanaan Model Pembelajaran Inkuiri Terbimbing Untuk Materi Sifat Koligatif Larutan Dan Pengaruhnya Terhadap Kemampuan Berpikir Kreatif Siswa Kelas Xii Ipa Sma Islam Al-Falah Kota Jambi,” J. Indo. Soc. Integ. Chem, vol. 9, no. 2, pp. 1-9, 2016.

[27] Astalini, D. A. Kurniawan, and A. D. Putri, "Identifikasi sikap implikasi sosial dari ipa, ketertarikan menambah waktu belajar ipa, dan ketertarikan berkarir dibidang ipa siswa smp se- kabupaten muaro jambi, ” J. Tarb. J. Ilm. Kependidikan, vol. 7, no. 2, pp. 93-108, 2018.

[28] D. Darmaji, D. A. Kurniawan, A. Suryani, and A. Lestari, “An Identification of Physics Pre-Service Teachers' Science Process Skills Through Science Process Skills-Based Practicum Guidebook," J. Ilm. Pendidik. Fis. AlBiruni, vol. 7, no. 2, p. 239, 2018, doi: 10.24042/jipfalbiruni.v7i2.2690.

[29] Maison, Darmaji, Astalini, D. A. Kurniawan, and P. S. Indrawati, "Science process skills and motivation," Humanit. Soc. Sci. Rev., vol. 7, no. 5, pp. 48-56, 2019, doi: 10.18510/hssr.2019.756.

[30] Darmaji, D. A. Kurniawan, H. Parasdila, and irdianti, "Description of Science Process Skills' Physics Education Students at Jambi University in Temperature and Heat Materials," Educ. Rev. USA, vol. 2, no. 9, pp. 485-498, 2018, doi: 10.26855/er.2018.09.004.

[31] Ssuci utami Putri, pembelajaran sains untuk anak usia dini. sumedang: UPI sumedang press, 2019.

[32] Darmaji, D. A. Kurniawan, Astalini, W. Kurniawan, K. Anwar, and A. Lumbantoruan, "Students ' perceptions of electronic's module in physics practicum," J. Educ. Learn., vol. 13, no. 2, pp. 288-294, 2019, doi: 10.11591/edulearn.v13i2.13005. 
[33] Syamsurizal, Haryanto, and N. Chairani, "Pengembangan E-Modul Berbasis Keterampilan Proses Sains Pada Materi Kesetimbangan Kimia Untuk Tingkat Sma," in Prosiding SEMIRATA 2015 bidang MIPA BKS-PTN Barat Universitas Tanjungpura, 2015, pp. 655-661.

[34] D. Darmaji, D. A. Kurniawan, and A. Lestari, "Deskripsi keterampilan proses sains mahasiswa pendidikan fisika pada praktikum suhu dan kalor," J. Ris. dan Kaji. Pendidik. Fis., vol. 5, no. 2, p. 68, 2018, doi: 10.12928/jrkpf.v5i2.10735.

[35] Astalini, D. A. Kurniawan, Darmaji, L. R. Sholihah, and R. Perdana, "Characteristics of students' attitude to Physics in Muaro Jambi High School," Humanit. Soc. Sci. Rev., vol. 7, no. 2, pp. 91-99, 2019, doi: 10.18510/hssr.2019.7210.

[36] A. L. Darmaji, Dwi Agus Kurniawan, Astalini, Wawan Kurniawan, Khairul Anwar, "Students' Perceptions of Electronic's Module in Physics Practicum,” J. Educ. Learn., vol. 13, no. 2, pp. 288-294, 2019, doi: 10.11591/edulearn.v13i2.13005.

[37] D. Darmaji, D. A. Kurniawan, A. Astalini, and N. R. Nasih, "Persepsi Mahasiswa pada Penuntun Praktikum Fisika Dasar II Berbasis Mobile Learning,” J. Pendidik. Teor. Penelitian, dan Pengemb., vol. 4, no. 4, pp. 516-523, 2019.

[38] Sugiyono, Metode Penelitian Pendidikan Pendekatan Kantitatif, Kualitatif, dan R\&D. Bandung: Alfabeta, 2017.

[39] N. Kruea-In and O. Thongperm, "Teaching of Science Process Skills in Thai Contexts: Status, Supports and Obstacles," Procedia - Soc. Behav. Sci., vol. 141, pp. 1324-1329, 2014, doi: 10.1016/j.sbspro.2014.05.228.

[40] T. Polyiem, P. Nuangchalerm, and P. Wongchantra, "Learning achievement, science process skills, and moral reasoning of ninth grade students learned by $7 \mathrm{e}$ learning cycle and socioscientific issue-based learning," Aust. J. Basic Appl. Sci., vol. 5, no. 10, pp. 257-264, 2011.

[41] A. H. Zeidan and M. R. Jayosi, "Science Process Skills and Attitudes toward Science among Palestinian Secondary School Students," World J. Educ., vol. 5, no. 1, pp. 13-24, 2015, doi: 10.5430/wje.v5n1p13.

[42] Astalini, Darmaji, W. Kurniawan, K. Anwar, and D. A. Kurniawan, "Effectiveness of using e-module and eassessment," Int. J. Interact. Mob. Technol., vol. 13, no. 9, pp. 21-39, 2019, doi: 10.3991/ijim.v13i09.11016. 